\title{
In vitro and in vivo activity of hyperimmune globulin preparations against multiresistant nosocomial pathogens
}

\author{
F. S. Rossmann $\cdot$ A. Kropec $\cdot$ D. Laverde $\cdot$ \\ F. R. Saaverda $\cdot$ D. Wobser $\cdot$ J. Huebner
}

Received: 12 August 2014 / Accepted: 13 November 2014 / Published online: 27 November 2014

(C) The Author(s) 2014. This article is published with open access at Springerlink.com

\begin{abstract}
Purpose We compared different immunoglobulin preparations containing $\operatorname{IgG}$ (Intraglobin/Intratect) or a mixture of IgG, IgA, and IgM (Pentaglobin) to assess the opsonic and protective efficacy of human immunoglobulin preparations against multiresistent nosocomial pathogens.

Materials and methods Clinical isolates of E. coli, Klebsiella pneumoniae, Pseudomonas aeruginosa, Enterococcus faecalis, Enterococcus faecium, and Staphylococcus aureus were tested by opsonophagocytic assay using immunologobulin preparations at dilutions usually obtained in patients. The target antigens of opsonic antibodies were characterized by opsonophagocytic inhibition assays, and the protective efficacy in vivo was tested in a mouse bacteremia model as previously described.

Results All strains were killed to at least $50 \%$ by Pentaglobin. One $P$. aeruginosa strain was not efficiently killed by Intraglobin $(23 \%)$ but the other strains were
\end{abstract}

F. S. Rossmann · A. Kropec · D. Laverde · F. R. Saaverda ·

D. Wobser $\cdot$ J. Huebner

Division of Infectious Diseases, Department of Medicine,

University Hospital Freiburg, Freiburg im Breisgau, Germany

\section{F. S. Rossmann}

Faculty of Biology, Albert-Ludwigs-University Freiburg, Freiburg University, Freiburg im Breisgau, Germany

\section{F. S. Rossmann · J. Huebner $(\bowtie)$}

Division of Pediatric Infectious Diseases, Department of Pediatrics, Dr. von Hauner Children's Hospital, Ludwig-Maximilians University, Munich, Germany

e-mail: jhuebner@med.uni-muenchen.de

F. S. Rossmann · A. Kropec · D. Laverde · F. R. Saaverda ·

D. Wobser · J. Huebner

German Center for Infection Research (DZIF),

Partnersite Munich, Munich, Germany killed by Intraglobin to a similar degree compared to Pentaglobin. Opsonic IgG antibodies against E. faecalis were directed against LTA, while opsonic antibodies in Pentaglobin were primarily directed against other cell wall carbohydrates. In a mouse bacteremia model, Pentaglobin was more protective than Intratect against Staphylococcus aureus, while Intratect reduced colony counts better than normal rabbit serum or saline.

Conclusions All tested human immunoglobulin preparations contain opsonic and protective antibodies against targets present on multiresistant Gram-positive and Gramnegative bacteria. Enrichment of these preparations with IgM increases the protective efficacy against some strains, probably due to antibodies directed against cell wall carbohydrates.

Keywords Immune globuline preparations $\cdot \operatorname{IgG} \cdot \operatorname{IgM}$. Nosocomial pathogens $\cdot$ Opsonic killing - Protective efficacy $\cdot$ Animal model

\section{Introduction}

Multiresistant nosocomial pathogens often cause life-threatening infections that are sometimes untreatable with currently available antibiotics and are therefore one of the most serious problems in modern medicine. A recent report from the Centers for Disease Control and Prevention (CDC) estimates that in the US about two million people acquire infections with resistant bacteria, and that probably about 23,000 patients die each year as a direct consequence of these infections [1]. Gram-positive bacteria account for a large proportion, and staphylococci and enterococci are the most important bacterial species causing these mostly hospital-acquired infections that often lead to extended hospital stay and excess 
mortality. Multiresistant Staphylococcus aureus cause pneumonia, skin, wound, bloodstream and surgical site infections. About 80,000 S. aureus infections have been reported in the US per year with about 12,000 deaths caused by bacteria resistant to methicillin (MRSA) [1]. High rates are also seen for enterococci, mainly Enterococcus faecium resistant to vancomycin (VRE) causing bloodstream infections, urinary tract infections, and foreign-body infections (e.g., catheters, stents, CNS shunts, artificial heart valves, etc.) mostly in immunocompromised patients [2-4]. For the US, it is estimated that about 66,000 enterococcal infections occur each year, and about 20,000 of these are due to multiple-drug resistant (i.e., VRE) with about 1,300 deaths per year [1]. Multiresistance in Gram-negative bacteria is mostly due to extended-spectrum betalactamases (ESBL) or carbapenemases. ESBL-producing Enterobacteriaceae are increasingly isolated in patients and even otherwise healthy individuals [5]. These bacteria can cause bloodstream infections and are responsible for approximately 26,000 cases and 1,700 deaths per year [1]. Especially worrisome is a novel threat associated with resistance determinants against carbapenems, currently the antibiotics with the broadest spectrum. In the US, more than 9,000 healthcare-associated infections are caused by carbapenem-resistant Enterobacteriaceae (K. pneumoniae and E. coli) and 600 deaths result from these infections each year [1]. Similar trends and incidences have been reported in Europe (http://www.ecdc.europa.eu/en/activities/surveillance/ EARS-Net/Pages/index.aspx).

Immunotherapy, either through active immunization, or by passive immunotherapy, is among the most promising alternative approaches to fight these strains $[4,6]$. While the development of novel vaccines against multiresistant nosocomial pathogens is pursued by many of the leading pharmaceutical companies, no preparation has yet been introduced into the market [7]. Passive immunotherapy, either through monoclonal antibodies, or through hyperimmunoglobulins, may be an attractive addition to the currently available treatment options. However, no good data exist to support the usage of these preparations to prevent and/or treat infections in hospitalized patients.

Intravenous application of immunoglobulins from healthy volunteers has been used for a number of indications, e.g., immunoglobulin substitution (i.v.) in patients with agammaglobulinemia, and as a supportive therapy for bacterial infections, Kawasaki disease, or Guillain-Barré syndrome. Most currently available antibody preparations contain only IgG and several studies could not demonstrate a benefit of these antibodies in the prevention and treatment of bacterial infections. However, in the initial immune response against bacterial pathogens, IgM plays an important role and the production of a compound containing not only $\operatorname{IgG}$ but also $\operatorname{IgA}$ and $\operatorname{IgM}$ may therefore offer the advantage of an "innate" immune protection against bacteria
[8]. Here, we investigate and compare the efficacy of protection of different antibody preparations with and without IgM and demonstrate that IgM provides a better protection in vivo and in vitro against some nosocomial pathogens.

\section{Materials and methods}

Bacterial strains, antibody preparations, and antigens

Bacterial strains, antibodies, and antigens used in this study are listed in Table 1. Immunoglobulin preparations were obtained from Biotest, and antigens were either produced in our lab according to previously described methods (i.e., LTA [9] or purchased from Sigma (St. Louis, MO).

\section{Opsonophagocytic assay}

Opsonophagocytic killing was assessed as described by Theilacker et al. [10] using $1.7 \%$ baby rabbit serum (Cedarlane) as complement source, and rabbit serum raised against purified lipoteichoic acid (anti-LTA) from E. faecalis 12030 as positive control [11-13]. Bacteria were incubated and grown to mid-exponential phase $\left(\mathrm{OD}_{650 \mathrm{~nm}}=0.400\right)$. Equal volumes of bacterial suspension $\left(2.5 \times 10^{7}\right.$ per $\left.\mathrm{mL}\right)$, leukocytes $\left(2.5 \times 10^{7}\right.$ per $\left.\mathrm{mL}\right)$, complement source (1.7\% final concentration), and either anti-LTA rabbit serum, immunoglobulin preparations or heat-inactivated immune rabbit serum (as control) were combined and incubated on a rotor rack at $37^{\circ} \mathrm{C}$ for $90 \mathrm{~min}$. After incubation, colony-forming units (CFUs) surviving in the tubes with bacteria were quantified by agar culture of serial dilutions. Percentage of killing was calculated by comparing the colony counts at $90 \mathrm{~min}(t 90)$ of a control without PMNs $\left(\mathrm{PMN}^{\text {neg }}\right)$ to the colony counts of a tube that contained all four components using the follow-

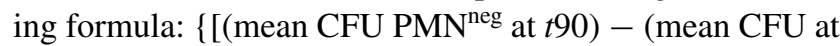
$t 90)] /\left(\right.$ mean CFU PMN ${ }^{\text {neg }}$ at $\left.\left.t 90\right)\right\} \times 100$.

Proteinase $\mathrm{K}$ and sodium meta-periodate treatment for inhibition experiments

Bacterial strain E. faecalis 12030 was cultured overnight in $\mathrm{TSB}$, harvested by centrifugation $\left(8,000 \mathrm{rpm}, 10 \mathrm{~min}, 4^{\circ} \mathrm{C}\right)$, and washed three times with PBS. Treatment of bacterial cells with proteinase $\mathrm{K}$ was performed as described previously [14]. In brief, bacterial cells $\left(\approx 10^{9} \mathrm{cfu} / \mathrm{mL}\right)$ were incubated with proteinase $\mathrm{K}$ (Sigma) at a final concentration of $0.1 \mathrm{mg} / \mathrm{mL}$ and $5 \mathrm{mM}$ calcium chloride at $54{ }^{\circ} \mathrm{C}$ during $4 \mathrm{~h}$. Treated cells were heat inactivated at $65^{\circ} \mathrm{C}$ for $1 \mathrm{~h}$, washed three times with PBS, and adjusted to a final concentration of $2.5 \times 10^{11} \mathrm{cfu} / \mathrm{mL}$ in PBS for the opsonophagocytic inhibition assay. For sodium meta-periodate treatment [15], 
Table 1 Bacterial strains, antigens and antisera used in this study

\begin{tabular}{|c|c|c|}
\hline Bacteria & Origin & Reference/provider \\
\hline E. faecalis 12030 & Clinical isolate, Cleveland, OH, (gift from D. Shlaes) & {$[14]$} \\
\hline E. coli 4263 & Outbreak isolate, strain collection University Hospital Freiburg & \\
\hline E. faecium 1162 & Isolated from blood in the Netherlands, $\mathrm{CC} 17$ & [27] \\
\hline K. pneumonia 1436 & Outbreak isolate, strain collection University Hospital Freiburg & \\
\hline K. pneumonia $1437 \mathrm{ESBL}$ & Outbreak isolate, strain collection University Hospital Freiburg & \\
\hline P. aeruginosa 2790 carbapenemase resistant & Outbreak isolate, strain collection University Hospital Freiburg & \\
\hline S. aureus LAC & CA-MRSA (USA300) & {$[28]$} \\
\hline VRSA-I & $\begin{array}{l}\text { Vancomycin-resistant } S \text {. aureus (NARSA) http://www.niaid.nih. } \\
\text { gov/labsandresources/resources/dmid/narsa/Pages }\end{array}$ & [29] \\
\hline \multicolumn{3}{|l|}{ Antigens } \\
\hline LTA & Lipoteichoic acid from E. faecalis 12030 & [9] \\
\hline LTA & Lipoteichoic acid from Streptococcus (Enterococcus) faecalis & Sigma \\
\hline \multicolumn{3}{|l|}{ Antisera } \\
\hline Intratect & Contains only IgG (100 mg/mL) & Biotest \\
\hline Intraglobin & $\begin{array}{l}\text { Contains only IgG }(50 \mathrm{mg} / \mathrm{mL}) \text {, same donor pool as Pentaglobin } \\
\text { (discontinued) }\end{array}$ & Biotest \\
\hline Pentaglobin & $\begin{array}{l}6 \mathrm{mg} \operatorname{IgM}, 6 \mathrm{mg} \operatorname{IgA} \text { and } 38 \mathrm{mg} \operatorname{IgG}(50 \mathrm{mg} / \mathrm{mL}) \text {, same donor pool } \\
\text { as Intraglobin }\end{array}$ & Biotest \\
\hline
\end{tabular}

bacterial cells $\left(\approx 10^{9} \mathrm{cfu} / \mathrm{mL}\right)$ were incubated with sodium meta-periodate at a final concentration of $1 \mathrm{M}$ for $24 \mathrm{~h}$ at room temperature in the dark. Sodium meta-periodate was neutralized with an excess of ethylene glycol at a final concentration of $2 \mathrm{M}$. Treated cells were washed three times with PBS and adjusted to a final concentration of $2.5 \times 10^{11}$ $\mathrm{cfu} / \mathrm{mL}$ in PBS for opsonophagocytic inhibition assay.

\section{Opsonophagocytic inhibition assay}

For inhibition studies, either pre-treated bacterial cells or lipoteichoic acid was used as inhibitor. Pentaglobin $(50 \mathrm{mg} / \mathrm{mL})$ and Intratect $(100 \mathrm{mg} / \mathrm{mL})$ were diluted $1: 25$ and incubated for $60 \mathrm{~min}$ at $4{ }^{\circ} \mathrm{C}$ with an equal volume of a solution containing $1.25 \times 10^{11} \mathrm{cfu} / \mathrm{mL}$ of treated bacterial cells or $100,20,4$ or $0.08 \mu \mathrm{g} / \mathrm{mL}$ of either lipoteichoic acid purified in our lab from E. faecalis 12030 or lipoteichoic acid from S. faecalis (E. faecalis) purchased from Sigma (St. Louis, Mo.). Subsequently, the respective mixtures of antibody and inhibitor was used in the opsonophagocytic assay (OPA) as described above. Inhibition assays were performed at serum dilutions yielding 50-80 \% killing of the inoculum without the addition of the inhibitor. The percentage of inhibition of opsonophagocytic killing was compared to controls without inhibitor.

\section{Animal experiments}

The protective efficacy of the monoclonal antibodies was tested against CA-MRSA strain LAC in a mouse bacteremia model as described previously [11]. Five female $\mathrm{BALB} / \mathrm{c}$ 6- to 8-week-old mice per group (Charles River Laboratories Germany $\mathrm{GmbH}$ ) were infected by i.v. injection of CA-MRSA $\left(5.0 \times 10^{7} \mathrm{cfu}\right)$ via the tail vein. Antibodies were given 48 and $24 \mathrm{~h}$ i.p. prior to bacterial challenge. Mice were killed $48 \mathrm{~h}$ after infection and organs (livers and kidneys) were aseptically removed, weighted and homogenized. Bacterial counts were enumerated after overnight incubation by plating serial dilutions on tryptic soy agar (TSA) plates. Statistical significance was assessed by Mann-Whitney test [12].

All animal experiments were performed in compliance with the German animal protection law (TierSchG). The animals were housed and handled in accordance with good animal practice as defined by FELASA and the national animal welfare body GV-SOLAS. The animal welfare committees of the University of Freiburg (Regierungspraesidium Freiburg Az 35/9185.81/G-12/070) approved all animal experiments. The institutional review board of the University of Freiburg approved the study protocol.

\section{Results}

To assess the role of the IgM component with regard to opsonic killing, we compared Pentaglobin (IgG, IgM and IgA) with Intraglobin (only $\operatorname{IgG}$ ). For the production of Intraglobin the same donor pool was used as for Pentaglobin.

Comparing the IgM-containing compound with the IgG compound against Gram-negative bacteria, significant 
killing was seen against ESBL-producing strain $K$. pneumoniae 1437 at a dilution of 1:10 (i.e., $68 \%$ killing with Pentaglobin and $61 \%$ with Intraglobin) (Fig. 1a). Higher killing could be observed in K. pneumoniae 1436, which at a dilution of 1:10 showed the best killing using Pentaglobin $(83 \%)$ and Intraglobin (95\%) (Fig. 1b). Clearly, less killing was observed in E. coli $4263(47 \%)$ and P. aeruginosa $2790(58,8 \%)$ using Pentaglobin, and even less killing was seen with Intraglobin (28\% for E. coli 4263 and $23 \%$ for P. aeruginosa 2790) (Fig. 1c, d). Overall, the IVIG preparation containing IgM shows higher killing rates in comparison to pure IVIG preparation Intraglobin against Gram-negative bacteria (Fig. 1).

To compare the IgM-containing compound with the pure IgG preparation against Gram-positive bacteria, killing rates of Pentaglobin and Intraglobin were also compared against several nosocomial Gram-positive pathogens. Killing against vancomycin-resistant $S$. aureus was significantly higher with Pentaglobin (71\%) at a 1:10 dilution in comparison to Intraglobin (41\%) (Fig. 2a). However,
Fig. 1 Opsonophagocytic killing of ESBL-producing strain K. pneumoniae 1437 (a), K. pneumoniae 1436 (b), E. coli 4263 (c), and carbapenemresistant $P$. aeruginosa 2790 (d). Opsonophagocytic assay was performed as described by Theilacker et al. using baby rabbit serum as complement source. IVIG preparations show significant opsonic killing against both K. pneumoniae strains. Higher killing against E. coli and $P$. aeruginosa was observed using Pentaglobin in comparison to Intraglobin. Killing is measured at dilutions of 1:10,1:50,1:100,1:200 and 1:500. Killing was dose dependent with both immunoglobulin preparations
A
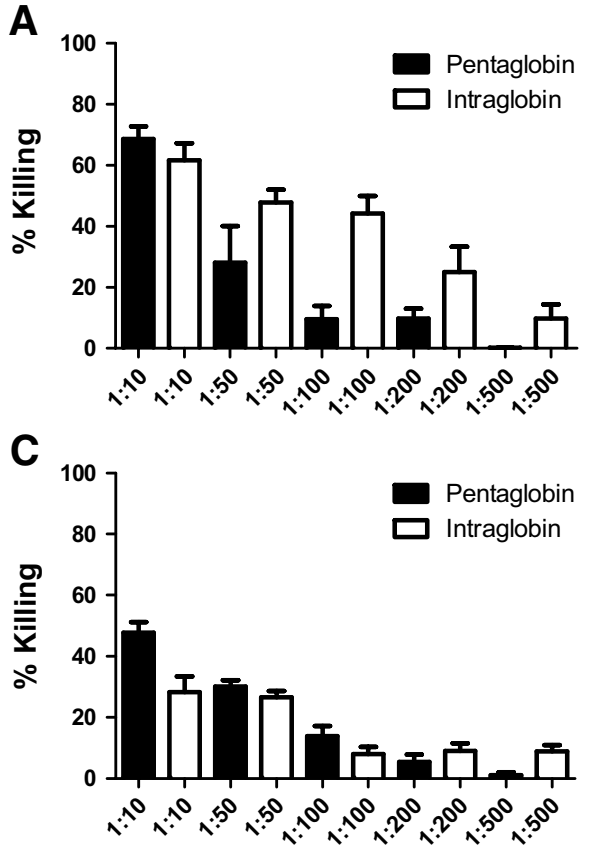

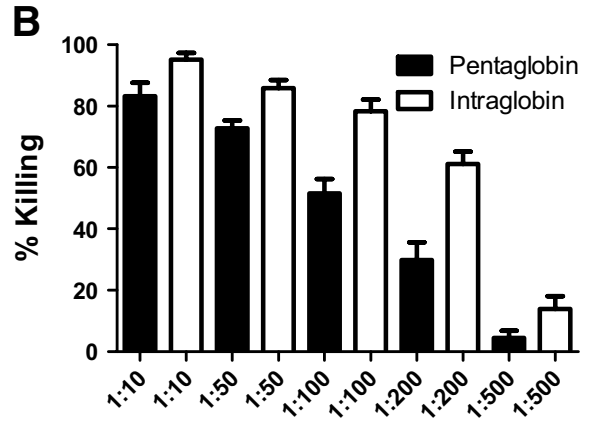

D

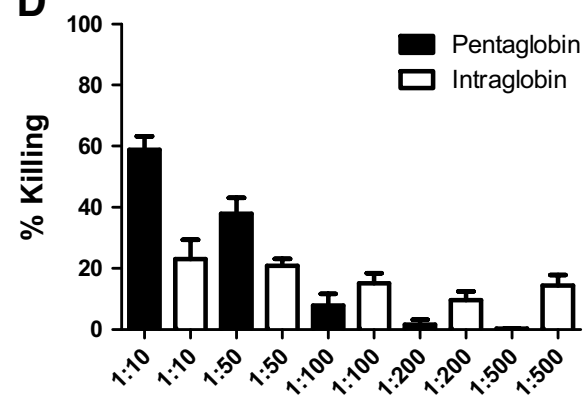

Fig. 2 Opsonophagocytic killing of VRSA-I strain (a), CA-MRSA LAC (b), E. faecalis 12030 (c), and E. faecium 1162 (d). Opsonophagocytic assay was performed as described by Theilacker et al. using baby rabbit serum as complement source. IVIG preparations show significant opsonic killing against all tested strains. Killing is measured at dilutions of 1:10, 1:50, 1:100, 1:200 and 1:500. Killing was dose dependent with both immunoglobulin preparations
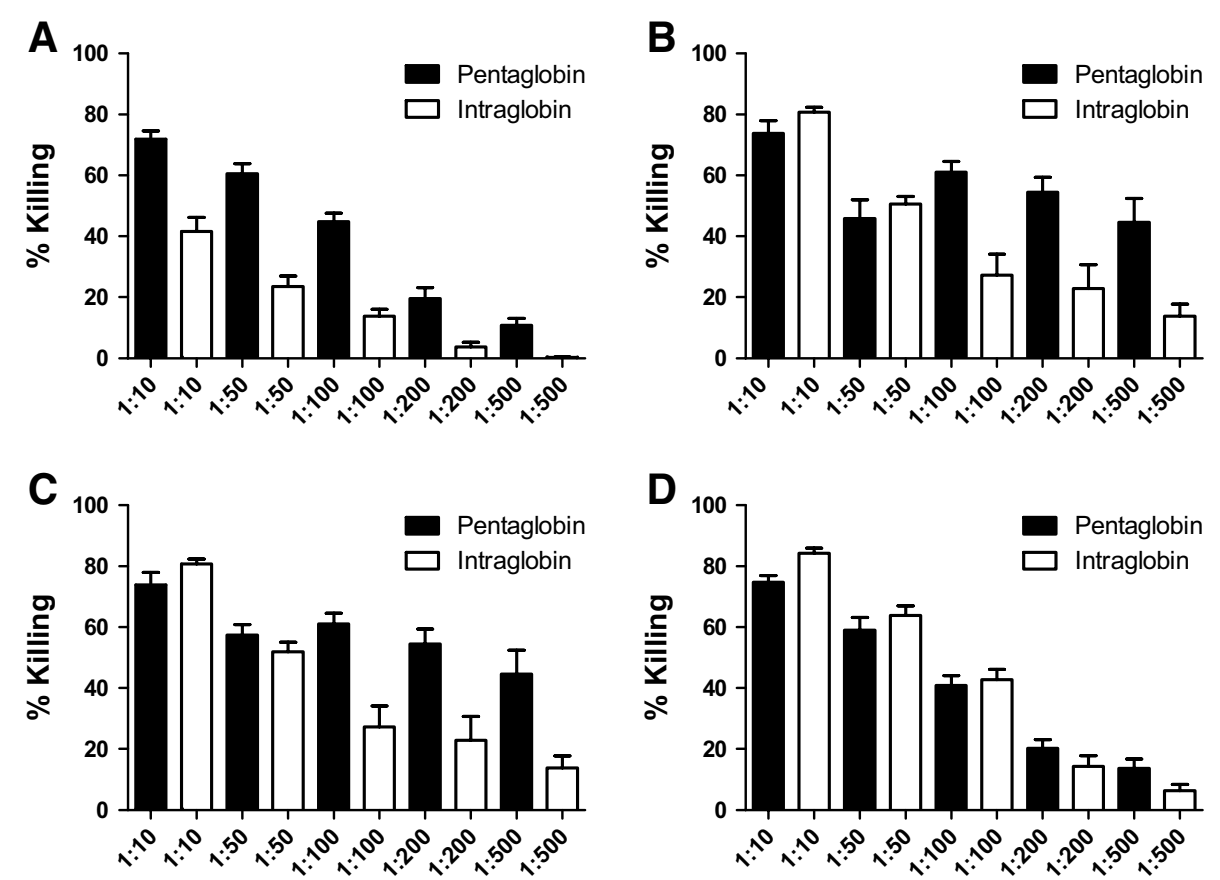


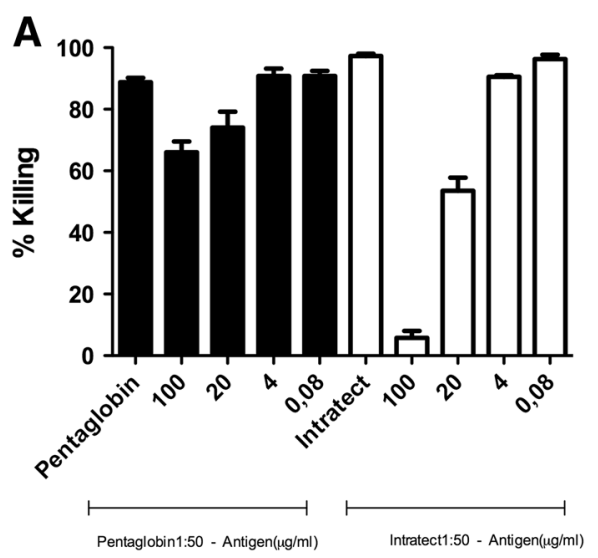

Fig. 3 Opsonophagocytic inhibition assay comparing the target of Pentaglobin and Intratect. a Lipoteichoic acid is the target of opsonic antibodies against E. faecalis 12030 in Intratect, while Pentaglobin is only partially directed against LTA. b Opsonophagocytic inhibition assay after treating E. faecalis 12030 with proteinase $\mathrm{K}$ or $\mathrm{NaIO}_{4}$. Opsonic activity of Intratect is significantly inhibited when bacteria are treated with proteinase $\mathrm{K}(70 \%)$ and inhibited by $30 \%$ when bacteria are treated with $\mathrm{NaIO}_{4}$. Pentaglobin is only partially inhib-

opsonic killing against CA-MRSA, E. faecalis as well as $E$. faecium was higher with Intraglobin (80-84 \%) in comparison to Pentaglobin (73-74\%) (Fig. 2).

To assess the bacterial targets of the opsonic antibodies in the various immunoglobulin preparations, Pentaglobin and Intratect (the current commercially available IgG preparation), were used in an opsonophagocytic inhibition assay [16]. Since our previous results indicated that the glycerol phosphate backbone of LTA is the predominant target of protective antibodies against Gram-positive bacteria [12], we used an LTA preparation for absorptions, indicating that opsonic IgG antibodies against E. faecalis in Intratect are directed against this epitope. Using the IgM-containing compound, only minimal absorption of killing was observed with purified LTA, indicating that the majority of opsonic antibodies in this preparation are not directed against this antigen (Fig. 3a). Opsonic killing activity of Intratect was inhibited with bacterial cells either treated with sodium meta-periodate or proteinase $\mathrm{K}$, suggesting that about $70 \%$ of the antibodies of Intratect are directed against a polysaccharide target and $30 \%$ against bacterial protein antigens. In contrast, opsonic antibodies in Pentaglobin are only partially absorbed by bacterial cells treated with $\mathrm{NaIO}_{4}$ but quite efficiently by bacteria treated with proteinase $\mathrm{K}$. This indicates that the majority of opsonic antibodies in this preparation are directed against carbohydrate antigens, while a smaller number of opsonic antibodies are also directed against protein antigens (Fig. 3b).

Using a previously described mouse sepsis model, we assessed the protective efficacy of the two antibody

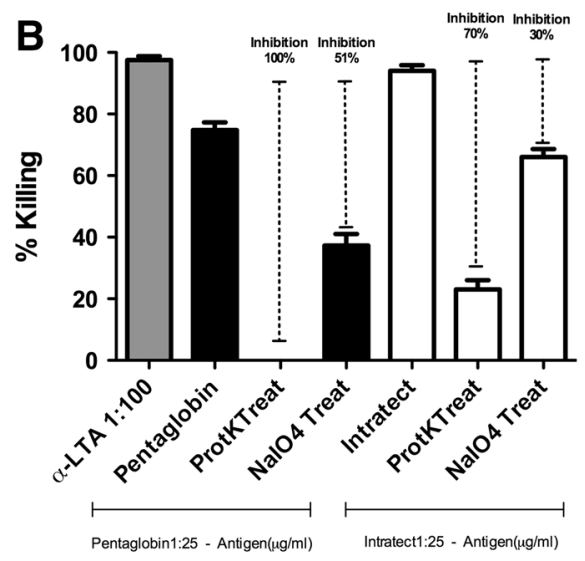

ited with the cells treated with $\mathrm{NaIO}_{4}$ indicating that the majority of the antibodies are directed against polysaccharides and some are directed against protein antigens. The gray bar shows Killing against E. faecalis 12030 when sera raised against LTA from E. faecalis 12030 were used and represent the positive control within this experiment. Intratect and Pentaglobin were diluted 1:25 for the inhibition assay

preparations in vivo (Fig. 4). Numbers of bacteria in liver and kidney of animals infected with MRSA strain LAC were significantly lower $\left(1.0 \times 10^{4} \mathrm{cfu} / \mathrm{g}\right.$ kidney and $1.9 \times 10^{4} \mathrm{cfu} / \mathrm{g}$ liver) when animals received the $\mathrm{IgG} / \mathrm{IgM}$ preparation Pentaglobin $(300 \mathrm{mg} / \mathrm{kg})$ compared to animals treated with Intratect $\left(4.5 \times 10^{4} \mathrm{cfu} / \mathrm{g}\right.$ kidney and $4.0 \times 10^{4}$ cfu/g liver).

\section{Discussion}

The concept of using polyclonal human antibody preparations to treat and/or prevent bacterial infections has been pursued for a long time [17, 18]. However, results so far are rather disappointing. A large meta-analysis about the usage of IVIG in preterm neonates to prevent infectious complications found a rather low reduction of about $3 \%$ in sepsis. However, this was not associated with a reduction in other clinically important outcomes, including mortality [19]. Similar observation has been made in other clinical settings [20].

The role of $\operatorname{IgM}$ is predominantly in the primary immune response of bacterial infections, and IgM eventually hypermutates and undergoes isotype switching [21]. Nevertheless, in many bacterial infections, the protective immune response is directed against carbohydrate antigens (such as capsular polysaccharides or glycoconjugates, such as teichoic acids) that are classic "T cell independent antigens" and do not lead to isotype switching and memory B cell generation [22]. These antibodies seem to be critically important for the first-line defense against common bacterial pathogens $[8,21]$. 


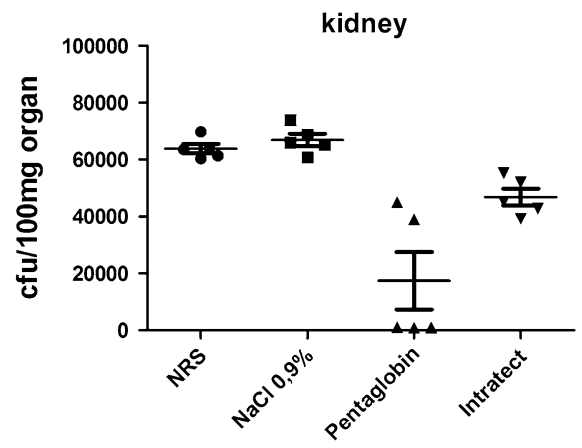

Fig. 4 Mouse bacteria sepsis model using CA-MRSA. Bacteria mouse sepsis was performed as described by Bao et al. The numbers of bacteria recovered from the kidney (a) and liver (b) of mice infected i.v. with $S$. aureus LAC were significantly lower $\left(1.0 \times 10^{4}\right.$

Only one commercially available antibody preparation, Pentaglobin, contains significant amounts (12\%) of IgM. In one study, this compound significantly reduced mortality, but had no overall effect on ICU length of stay [23]. On the other hand, Tugrul and colleagues [24] did not see such an effect and concluded that Pentaglobin did not have a positive effect on morbidity, incidence of septic shock, and mortality. Berlot et al. [20] pointed out that in general, the timing of the application of IVIG preparations is probably related to efficiency, similar to broad-spectrum antibiotics. The effect of IgM may also not be only directed against bacterial pathogens but may in addition lead to a modified anti-inflammatory response, such as up-regulation of IL-10 or down-regulation of IL-1 [25]. The selection of the study population and the overall study design seem to be of importance, because there are strong indications that certain subgroups, such as patients with streptococcal toxic shock syndrome caused by group A streptococcus, will benefit [26], while other more heterogeneous study populations may not exhibit positive results.

In our study, both antibody preparations showed broadly cross-reactive antibodies against the most notorious multiresistant pathogens, leading to significant opsonic killing of $50 \%$ and higher at concentrations of $1.25 \mathrm{mg} / \mathrm{mL}$ against most of the strains tested. This amount corresponds to the human situation where similar amounts of immunoglobulin should be obtained with the recommended doses of Pentaglobin or Intratect. Pentaglobin clearly showed better protection at lower dilutions (as low as $125 \mu \mathrm{g} / \mathrm{mL}$ ), while Intraglobin did not show significant killing at these dilutions. Since the only difference between these preparations is the $\operatorname{IgM}$ (and $\operatorname{IgA}$ ) content of Pentaglobin, this may indicate that the opsonic and protective antibodies are IgM.

At least against $E$. faecalis, the target of opsonic $\operatorname{IgG}$ antibodies seems to be lipoteichoic acid, since absorption with purified LTA abrogated killing of this strain. For Pentaglobin, absorption with LTA did not result in significant inhibition of

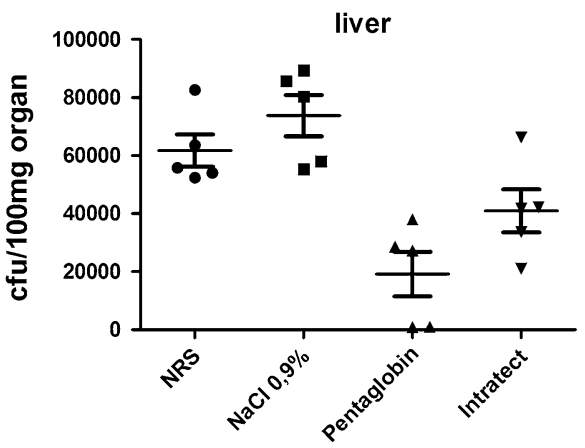

cfu/g kidney and $1.9 \times 10^{4} \mathrm{cfu} / \mathrm{g}$ liver) when animals received the $\mathrm{IgG} / \mathrm{IgM}$ preparation Pentaglobin $(300 \mathrm{mg} / \mathrm{kg})$ compared to animals treated with Intratect $\left(4.5 \times 10^{4} \mathrm{cfu} / \mathrm{g}\right.$ kidney and $4.0 \times 10^{4} \mathrm{cfu} / \mathrm{g}$ liver)

killing, although the majority of killing was abrogated after absorption with proteinase-treated bacterial cells. This indicates that the targets of protective antibodies of both preparations differ to some extent, but are mainly directed against carbohydrate antigens (such as capsular polysaccharides). Killing in the opsonophagocytic assay is usually expressed in percent, although the effect is logarithmic. This explains the observation that inhibition with proteinase-K-treated bacteria treated with Na-periodate does not add up to $100 \%$. The animal model clearly shows protection against bacterial infections by both antibody preparations, although lower bacterial counts were observed with Pentaglobin, compared to Intratect. Together, our data indicate that human immunoglobulin preparations contain opsonic and protective antibodies against targets present on multiresistant Gram-positive and Gram-negative bacteria. Enrichment of these preparations with IgM increases the protective efficacy, probably due to antibodies directed against cell wall carbohydrates. Additional studies in well-defined clinical settings should confirm these findings.

Acknowledgments The authors wish to thank Prof. D. Jonas (Institute for Environmental Health Sciences and Hospital Infection Control, University Hospital Freiburg) for strains.

Conflict of interest This study was supported by a grant from Biotest, Dreieich (Germany) to the University Hospital Freiburg.

Open Access This article is distributed under the terms of the Creative Commons Attribution License which permits any use, distribution, and reproduction in any medium, provided the original author(s) and the source are credited.

\section{References}

1. Centers for Disease Control and Prevention CDC. Antibiotic resistance threats in the United States 2013 Internet www.cdc.gov 2013 cited 2014 Jul 3. pp. 1-114. Available from: http://www.cdc. gov/drugresistance/threat-report-2013/. 
2. Huebner J, Arciola CR. Cave enterococcum! Int J Artif Organs. 2007;30:852-3.

3. Fabretti F, Huebner J. Implant infections due to enterococci: role of capsular polysaccharides and biofilm. Int J Artif Organs. 2005;28:1079-90.

4. Koch S, Hufnagel M, Theilacker C, Huebner J. Enterococcal infections: host response, therapeutic, and prophylactic possibilities. Vaccine. 2004;22:822-30.

5. Talbot GH, Bradley JS, Edwards JE, Rice LB, Spellberg B. Bad bugs, no drugs: no ESKAPE! an update from the Infectious Diseases Society of America. Clin Infect Dis. 2009;48:1-12.

6. Fox JL. Anti-infective monoclonals step in where antimicrobials fail. Nat Biotechnol. 2013;31:952-4.

7. Shinefield H, Black S, Fattom A, Horwith G, Rasgon S, Ordonez $\mathrm{J}$, et al. Use of a Staphylococcus aureus conjugate vaccine in patients receiving hemodialysis. N Engl J Med. 2002;346:491-6.

8. Weller S, Braun MC, Tan BK, Rosenwald A, Cordier C, Conley ME, et al. Human blood IgM "memory" B cells are circulating splenic marginal zone B cells harboring a prediversified immunoglobulin repertoire. Blood. 2004;104:3647-54.

9. Theilacker C, Kaczynski Z, Kropec A, Fabretti F, Sange T, Holst O, et al. Opsonic antibodies to Enterococcus faecalis strain 12030 are directed against lipoteichoic acid. Infect Immun. 2006;74:5703-12.

10. Theilacker C, Sanchez-Carballo P, Toma I, Fabretti F, Sava I, Kropec A, et al. Glycolipids are involved in biofilm accumulation and prolonged bacteraemia in Enterococcus faecalis. Mol Microbiol. 2009;71:1055-69.

11. Hufnagel M, Koch S, Creti R, Baldassarri L, Huebner J. A putative sugar-binding transcriptional regulator in a novel gene locus in Enterococcus faecalis contributes to production of biofilm and prolonged bacteremia in mice. J Infect Dis. 2004;189:420-30.

12. Theilacker C, Kropec A, Hammer F, Sava I, Wobser D, Sakinc T, et al. Protection against Staphylococcus aureus by antibody to the polyglycerolphosphate backbone of heterologous lipoteichoic acid. J Infect Dis. 2012;205:1076-85.

13. Theilacker C, Kaczynski Z, Kropec A, Sava I, Ye L, Bychowska A, et al. Serodiversity of opsonic antibodies against Enterococcus faecalis-glycans of the cell wall revisited. PLoS One. 2011;6:e17839.

14. Huebner J, Wang Y, Krueger WA, Madoff LC, Martirosian G, Boisot $\mathrm{S}$, et al. Isolation and chemical characterization of a capsular polysaccharide antigen shared by clinical isolates of Enterococcus faecalis and vancomycin-resistant Enterococcus faecium. Infect Immun. 1999;67:1213-9.

15. Sava IG, Zhang F, Toma I, Theilacker C, Li B, Baumert TF, et al. Novel interactions of glycosaminoglycans and bacterial glycolipids mediate binding of enterococci to human cells. J Biol Chem. 2009;284:18194-201.

16. Kropec A, Sava IG, Vonend C, Sakinc T, Grohmann E, Huebner J. Identification of SagA as a novel vaccine target for the prevention of Enterococcus faecium infections. Microbiology. 2011;157:3429-34.
17. Wilson PC, Andrews SF. Tools to therapeutically harness the human antibody response. Nat Rev Immunol. Nature Publishing Group; 2012;12:709-19.

18. Hufnagel M, Sixel K, Hammer F, Kropec A, Sava IG, Theilacker $\mathrm{C}$, et al. Detection of opsonic antibodies against Enterococcus faecalis cell wall carbohydrates in immune globulin preparations. Infection. Springer Berlin Heidelberg; 2014;42:749-55.

19. Ohlsson A, Lacy JB. Intravenous immunoglobulin for preventing infection in preterm and/or low birth weight infants. In: Ohlsson A, editor. Cochrane database of systematic reviews (Online). Chichester: John Wiley \& Sons, Ltd; 2013;7:CD000361.

20. Berlot G, Vassallo MC, Busetto N, Bianchi M, Zornada F, Rosato I, et al. Relationship between the timing of administration of IgM and IgA enriched immunoglobulins in patients with severe sepsis and septic shock and the outcome: a retrospective analysis. J Crit Care. 2012;27:167-71.

21. Grönwall C, Vas J, Silverman GJ. Protective roles of natural IgM antibodies. Front Immunol. 2012;3:66.

22. Mond JJ, Lees A, Snapper CM. T cell-independent antigens type 2. Annu Rev Immunol. 1995;13:655-92.

23. Neilson AR, Burchardi H, Schneider H. Cost-effectiveness of immunoglobulin M-enriched immunoglobulin (Pentaglobin) in the treatment of severe sepsis and septic shock. J Crit Care. 2005;20:239-49.

24. Tugrul S, Ozcan PE, Akinci O, Seyhun Y, Cagatay A, Cakar N, et al. The effects of IgM-enriched immunoglobulin preparations in patients with severe sepsis [ISRCTN28863830]. Crit Care. 2002;6:357-62.

25. Barratt-Due A, Sokolov A, Gustavsen A, Hellerud BC, Egge K, Pischke SE, et al. Polyvalent immunoglobulin significantly attenuated the formation of IL-1 $\beta$ in Escherichia coli-induced sepsis in pigs. Immunobiology. Elsevier GmbH; 2013;218:683-9.

26. Norrby-Teglund A, Kotb M. Cytokine patterns in severe invasive group A streptococcal infections. In: Kotb M, Calandra T, editors. Cytokines and chemokines in infectious diseases handbook. Humana Press Inc; 2003. pp. 77-92.

27. Heikens E, Bonten MJM, Willems RJL. Enterococcal surface protein Esp is important for biofilm formation of Enterococcus faecium E1162. J Bacteriol. 2007;189:8233-40.

28. Pang YY, Schwartz J, Thoendel M, Ackermann LW, Horswill AR, Nauseef WM. agr-Dependent interactions of Staphylococcus aureus USA300 with human polymorphonuclear neutrophils. J Innate Immun. 2010;2:546-59.

29. Saravolatz LD, Pawlak J, Johnson LB. In vitro susceptibilities and molecular analysis of vancomycin-intermediate and vancomycin-resistant Staphylococcus aureus isolates. Clin Infect Dis. 2012;55:582-6. 